\title{
Comparative Study Between Sensitization Degree of the 0.4\% Mo Austenitic Stainless Steel and UNS S31803 Duplex Stainless Steel
}

\author{
José C. de Lacerda * (D), Lucas L. de Freitas ${ }^{a}$, Rogério F. Brito ${ }^{a}$, \\ Francisco Moura Filho ${ }^{a}$, Ricardo L.P. Teixeira ${ }^{a}$ (D) \\ ${ }^{a}$ Universidade Federal de Itajubá, Itabira, $M G$, Brasil
}

Received: October 7, 2020; Revised: November 30, 2020; Accepted: December 13, 2020

\begin{abstract}
This study aims at assessing the degree of susceptibility to intergranular corrosion of the UNS S31803 duplex stainless steel and the $0.4 \%$ Mo austenitic stainless steel through the double-loop electrochemical potentiodynamic reactivation (DL-EPR) test. Both steels were subjected to isothermal treatments at $650^{\circ} \mathrm{C}$ and $900^{\circ} \mathrm{C}$ in order to compare the effect of temperature on the respective degrees of sensitization. It was observed that the $0.4 \% \mathrm{Mo}$ austenitic stainless steel presented a higher degree of sensitization and, consequently, a greater susceptibility to the intergranular corrosion process when compared to the UNS S31803 duplex stainless steel in the two temperatures studied. It was also observed that, for both steels, the heat treatment at $900^{\circ} \mathrm{C}$ resulted in a higher degree of sensitization when compared to the heat treatment at $650^{\circ} \mathrm{C}$.
\end{abstract}

Keywords: intergranular corrosion, degree of sensitization, DL-EPR.

\section{Introduction}

Duplex stainless steels (DSS) are widely used in manufacturing critical components in different industrial fields, such as petrochemical, food, oil and nuclear industries. Their use has replaced austenitic steels in many applications because of their good combination of high strength properties and toughness with high corrosion resistance in aggressive environments. The good mechanical properties exhibited by duplex stainless steels are due to their microstructure consisting of approximately the same amounts of austenite and ferrite. However, during some manufacturing processes, such as electric arc welding, the steel is subjected to high temperatures, which may lead to the formation of other phases. Among these phases, it is necessary to consider the sigma phase, which has its highest incidence in the temperature range between $650^{\circ} \mathrm{C}$ and $900^{\circ} \mathrm{C}$. The sigma phase has high kinetic formation and its presence dramatically decreases the properties of impact strength and corrosion resistance ${ }^{1}$. Intergranular corrosion is a type of selective attack that propagates through the grain boundaries of stainless steels considered to be sensitive. Intergranular corrosion is localized and extremely difficult to detect, mainly due to the minimal loss of mass and small size of the attacked region ${ }^{2}$. The precipitation of carbides and phases may promote the sensitization of stainless steels, making them susceptible to intergranular corrosion ${ }^{3}$.

Chromium carbides are the precipitates that are most impacted by the phenomenon of intergranular corrosion in stainless steels. The formation of chromium carbides occurs by diffusion and focuses mainly on the grain boundaries of the material. With this localized diffusion there is chromium depletion in the adjacencies of the grain boundary. This

*e-mail: jlacerda.cem@gmail.com chromium depletion region becomes anodic in the presence of an electrolyte ${ }^{4}$. Chromium depletion is the most accepted theory for the sensitization of stainless steels. In addition to chromium depletion, if stainless steel contains Mo, its depletion in the matrix caused by eventual precipitation of some intermetallic phases can also cause its sensitization. Zhang et al. ${ }^{5}$ concluded that in duplex stainless steels, intergranular corrosion can also occur by the combination of depleted zones in both chromium and molybdenum.

Austenitic stainless steels may also be susceptible to sensitization caused by the eventual formation of $\mathrm{Cr}$-rich phases such as $\mathrm{M}_{23} \mathrm{C}_{6}$. The $0.4 \%$ Mo austenitic stainless steel, studied in this paper, has lower chromium content $(17 \%)$ compared to AISI 304 austenitic stainless steel (18-20\%). However, both steels have approximately the same pitting corrosion resistance due to the presence of Mo in the first steel. The pitting corrosion resistance indicator of stainless steels can be obtained by calculating the PREN (Pitting Resistance Number) according to Equation $1^{6}$.

PREN $=\% C r+3.3(\% M o)+16(\% N)$

Although the PRENs of the two steels are approximately equal $(0.4 \%$ Mo steel $=18.3$ and AISI $304=18.0)$, there are no publications about Mo addition effects on the susceptibility to intergranular corrosion (sensitization) in $0.4 \%$ Mo austenitic stainless steel. As reported, the addition of molybdenum on $0.4 \%$ Mo austenitic stainless steel, was probably intended to compensate its lower chromium content compared to AISI 304 steel (also austenitic), in order to maintain its pitting potential.

The comparative study of the two steels, one with an austenitic structure $(0.4 \%$ Mo austenitic stainless steel) 
and the other with a biphasic structure austenite + ferrite (UNS S31803), aimed to better understand the susceptibility correlations to sensitization of themselves. The two studied steels can be competitive in many applications considering their distinct properties due to microstructural differences. In this case, in relation to resistance to pitting corrosion, this work presents important information on the behavior of the two steels when subjected to aging temperatures of $650^{\circ} \mathrm{C}$ and $900^{\circ} \mathrm{C}$. The results obtained are confirmed by the literature, but, in this work, they are based on quantitative data on the degree of sensitization of the two studied steels.

The aging temperatures of $650^{\circ} \mathrm{C}$ and $900^{\circ} \mathrm{C}$ were chosen due to the higher precipitation kinetics of the sigma phase (phase rich in $\mathrm{Fe}-\mathrm{Cr}-\mathrm{Mo}$ ) in this temperature range in stainless steels with the presence of molybdenum in its chemical composition.

To evaluate the susceptibility of steels to sensitization, electrochemical techniques are commonly employed. The electrochemical potentiodynamic reactivation (EPR) test was developed in $1969^{7}$. The EPR continues to the present day to be the most common method to evaluate the susceptibility to intergranular corrosion in the stainless steels. The EPR test is typically used in two ways: single-loop electrochemical potentiodynamic reactivation (SL-EPR) and dual-loop electrochemical potentiodynamic reactivation (DL-EPR) ${ }^{2,5}$. In general, the SL-EPR test has some disadvantages when compared to the DL-EPR test. Most of the time, the SL-EPR tests do not have satisfactory results in materials that have fine precipitates besides the requirement of an extremely fine polishing on the surface of the material $(1 \mu \mathrm{m})^{7}$. Thus, the DL-EPR test has been used more frequently in studies to evaluate the sensitization in stainless steels ${ }^{2,5,8}$.

The DL-EPR test is conducted using a potentiostat connected to a cell containing three electrodes: the working electrode, a reference electrode, and a counter electrode ${ }^{4}$. The method consists of the realization of an anodic scan starting at the potential of an open circuit going to a certain potential in the passive zone of the material. After this step, a reverse sweep is performed until the return to the open circuit potential ${ }^{9}$. Depending on the microstructure of the material, two current peaks are observed during the cycle: a peak in the anode direction of increasing sweep $\left(i_{a}\right.$ - activation current) and a peak in the reverse direction $\left(i_{r}\right.$ - reactivation current). The sensitization degree of the steels can be obtained by the ratio $i_{r} / i_{a}$ and / or by the ratio between the areas under the reverse scanning $\left(Q_{r}\right)$ and increasing scanning $\left(\mathrm{Q}_{\mathrm{a}}\right)$ anodic curves ${ }^{9}$. The closer a metal alloy's degree of sensitization is to 1.0 , the greater its susceptibility to intergranular corrosion. In this case, the higher the value of the reactivation current $\left(i_{r}\right)$, the lower the stability of the protective film and, therefore, the greater the susceptibility to localized corrosion.

\section{Experimental Procedures}

This research used samples of the $0.4 \%$ Mo austenitic stainless steel and UNS S31803 duplex stainless steel received in the form of plates in the thickness of $1.8 \mathrm{~mm}$. Table 1 shows the chemical composition of the samples obtained using a CS-400 carbon analyzer and ARL 4460 optical emission spectrometer. The Mo, Ni, Cr, and Mn compositions of the $0.4 \%$ Mo austenitic stainless steel were obtained by X-ray fluorescence spectrometry using a Thermo Fisher Scientific Niton Handheld XRF Analyzer spectrometer, model NITON XL2.

The samples were subjected to isothermal treatment at temperatures of $650^{\circ} \mathrm{C}$ and $900^{\circ} \mathrm{C}$ for 30 min followed by cooling in water. These temperatures were chosen because they comprise the range of greatest possibility of sigma phase precipitation. The kinetics for the formation of sigma phase in this temperature range is too high, thus the low aging time $^{1}$. DL-EPR tests were performed on 3 specimens of each of the steels studied in each heat treatment condition. The specimens were prepared from a $1 \mathrm{~cm}^{2}$ section of the 0.4\% Mo austenitic stainless steel and UNS S31803 steel sheets, and they were welded to a wire (for electrical contact) and embedded in polyester resin. For testing, the specimens were polished with $\mathrm{SiC}$ paper with 200 to 600 grit $(\mathrm{Ra}=0.128 \mathrm{~mm})$, washed with absolute ethanol and acetone, and dried with a hot air jet.

For DL-EPR tests, a potentiostat EmStat3 (PalmSens) was used on the three electrodes: the reference electrode saturated calomel (SCE), the counter platinum electrode, and the working electrode (specimen). The electrolyte used was an aqueous solution of $2 \mathrm{M} \mathrm{H} 2 \mathrm{SO} 4+0.5 \mathrm{M}$ $\mathrm{NaCl}+0.01 \mathrm{M} \mathrm{KSCN}^{1}$. The software used to obtain the polarization curves was PSTrace 4.2. Prior to the DL-EPR tests, the specimen was allowed to stabilize at the open circuit potential for $10 \mathrm{~min}$ at $20^{\circ} \mathrm{C}$. The open circuit corrosion potentials obtained were $-400 \mathrm{mV}$ (SCE) for $0.4 \%$ Mo austenitic stainless steel and $-450 \mathrm{mV}(\mathrm{SCE})$ for UNS S31803 steel.

The DL-EPR tests were performed three times on each sample. In the tests, the increasing scanning in the anodic direction from the corrosion potential were performed to approximately $300 \mathrm{mV}(\mathrm{SCE})$. Then, reverse scanning was performed in the opposite direction until reaching the respective open circuit corrosion potential of each sample. The DL-EPR tests were carried out with a scan rate of $1.67 \mathrm{mV}(\mathrm{SCE}) / \mathrm{s}^{2}$.

To reveal the microstructure, an electrolyte attack was used consisting of oxalic acid aqueous solution ( $10 \%$ by weight) at $3 \mathrm{~V}$ for $90 \mathrm{sec}$ in $0.4 \%$ Mo austenitic stainless steel and for 120 seconds in UNS S31803 steel. Steel microstructural analyses were performed using a VEGA 3 - TESCAN scanning electron microscope (SEM).

Table 1. Chemical composition of $0.4 \%$ Mo austenitic stainless steel ( 0.4 Mo Steel) and UNS S31803 stainless steel (wt $\%)$.

\begin{tabular}{ccccccccc}
\hline & $\mathrm{C}$ & $\mathrm{Si}$ & $\mathrm{Mn}$ & $\mathrm{Cr}$ & $\mathrm{Ni}$ & $\mathrm{Mo}$ & $\mathrm{N}$ & $\mathrm{Fe}$ \\
\hline 0.4Mo Steel & 0.06 & - & 0.9 & 17.0 & 8.6 & 0.4 & - & Balance \\
\hline UNS S31803 & 0.02 & 0.31 & 1.82 & 22.38 & 5.35 & 3.04 & 0.15 & Balance \\
\hline
\end{tabular}


Table 2. DL-EPR test results.

\begin{tabular}{ccccc}
\hline \multirow{2}{*}{ Steel } & \multirow{2}{*}{$\begin{array}{c}\text { Heat Treatment } \\
\left({ }^{\circ} \mathrm{C}\right)\end{array}$} & \multicolumn{2}{c}{$\begin{array}{c}\text { Average Peak Current } \\
\left(\mu \mathrm{A} / \mathrm{cm}^{2}\right)\end{array}$} & \multirow{2}{*}{$\begin{array}{c}\text { Degree of Sensitization } \\
\left(\mathrm{i}_{\mathrm{r}} / \mathrm{i}_{\mathrm{a}}\right)\end{array}$} \\
\cline { 2 - 4 } & 650 & $\mathrm{i}_{\mathrm{a}}$ & $\mathrm{i}_{\mathrm{r}}$ & $0.48 \pm 0.02$ \\
\cline { 2 - 5 } 0.4 Mo Steel & 900 & 0.0584 & 0.0281 & $0.75 \pm 0.01$ \\
\hline \multirow{2}{*}{ UNS S31803 } & 650 & 0.0829 & 0.0622 & $0.014 \pm 0.004$ \\
\cline { 2 - 4 } & 900 & 0.0036 & 0.00005 & $0.21 \pm 0.01$ \\
\hline
\end{tabular}
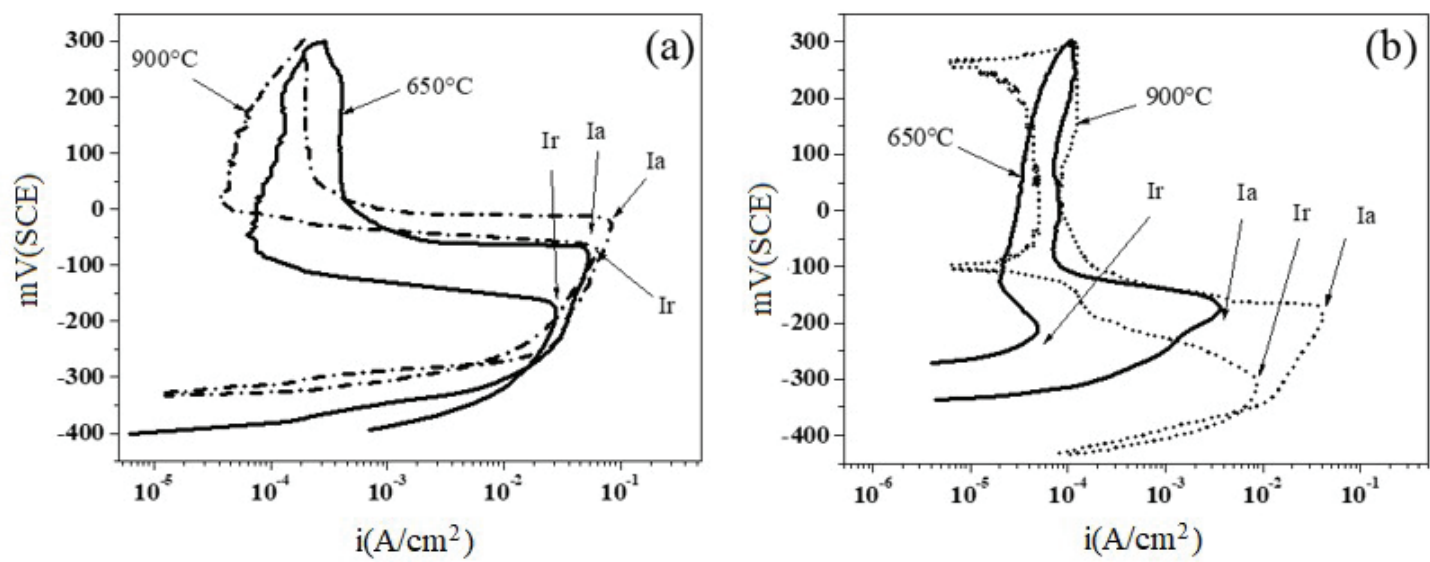

Figure 1. DL-EPR curves: (a) 0.4\% Mo austenitic stainless steel; (b) UNS S31803 duplex stainless steel.

\section{Results and Discussion}

Figure 1 shows the curves obtained by DL-EPR tests performed on samples of $0.4 \%$ Mo austenitic stainless steel and UNS S31803 duplex stainless steel. Both of the steels were annealed for $30 \mathrm{~min}$ at $650^{\circ} \mathrm{C}$ and $900^{\circ} \mathrm{C}$. The cooling of the samples was performed using water at room temperature. The DL-EPR tests started at the steel corrosion potential and were carried out with a scan rate of $1.67 \mathrm{mV}(\mathrm{SCE}) / \mathrm{s}$, as previously reported.

According to Zubair Khan et al. ${ }^{10}$, a passive film throughout the sample is formed in the activation scan of the DL-EPR tests. In the reverse scan there is the breakdown of the unstable passive film formed in the depleted chromium regions resulting in intergranular corrosion. In this case, the material matrix acts as a cathode (protective) and the chromium-depleted regions function as the sacrificial anode ${ }^{5}$. Table 2 shows the activation currents $\left(i_{\mathrm{a}}\right)$, reactivation currents $\left(i_{r}\right)$, and sensitization degrees observed in the DL-EPR curves of $0.4 \%$ Mo austenitic stainless steel (0.4Mo Steel) and UNS S31803 duplex stainless steel, as shown in Figure 1a, b.

As can be observed in Table 2 and Figure 2, the sensitization degrees $\left(i_{r} / i_{a}\right)$ were higher for both steels $(0.4 \%$ Mo austenitic stainless steel and UNS S31803 duplex stainless steel) when treated at $900^{\circ} \mathrm{C}$ compared with $650^{\circ} \mathrm{C}$. As a consequence of the sensitization process observed, both steels were more susceptible to intergranular corrosion at $900^{\circ} \mathrm{C}$ compared with $650^{\circ} \mathrm{C}$. It should also be noted from the results of degrees of sensitization (ir/ia) obtained that $0.4 \%$ Mo austenitic stainless steel presented greater susceptibility to intergranular corrosion compared with UNS S31803 steel at both temperatures considered.

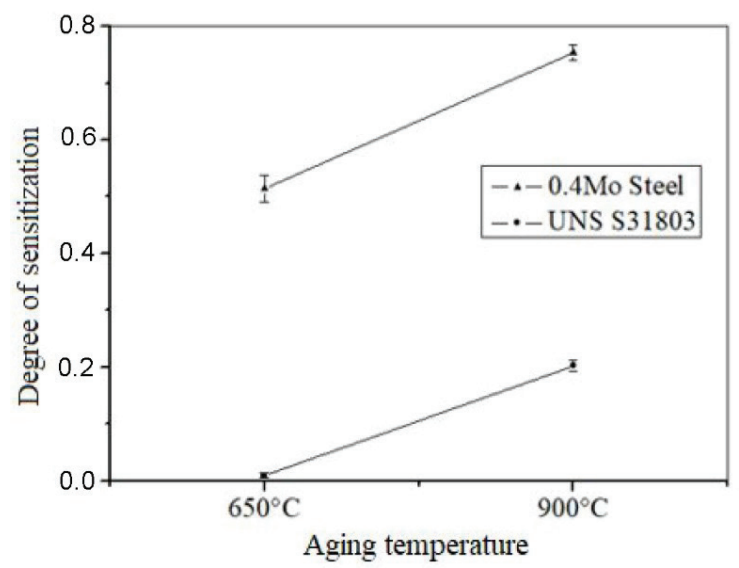

Figure 2. Sensitization degrees of $0.4 \%$ Mo austenitic stainless steel (0.4Mo Steel) and UNS S31803 duplex stainless steel annealed.

Figure $3 \mathrm{a}, \mathrm{b}$ shows the micrographs of $0.4 \%$ Mo austenitic stainless steel thermally aged at $650^{\circ} \mathrm{C}$ and $900^{\circ} \mathrm{C}$, for $30 \mathrm{~min}$, followed by cooling in water at room temperature. In both conditions, the austenitic microstructure $(\gamma)$ showed intergranular corrosion caused by precipitates in the grain boundaries (highlighted with arrows). Typical twin lines occurred in the microstructure of $0.4 \%$ Mo austenitic stainless steel at the two aging temperatures $\left(650^{\circ} \mathrm{C}\right.$ and $\left.900^{\circ} \mathrm{C}\right)$, as shown in Figure $3 \mathrm{a}, \mathrm{b}$. So, the corrosion attacks along them cannot be classified as intergranular corrosion, because the twins are inside the grains. Intergranular corrosion occurred with greater intensity in the grain boundary of the sample aged at 

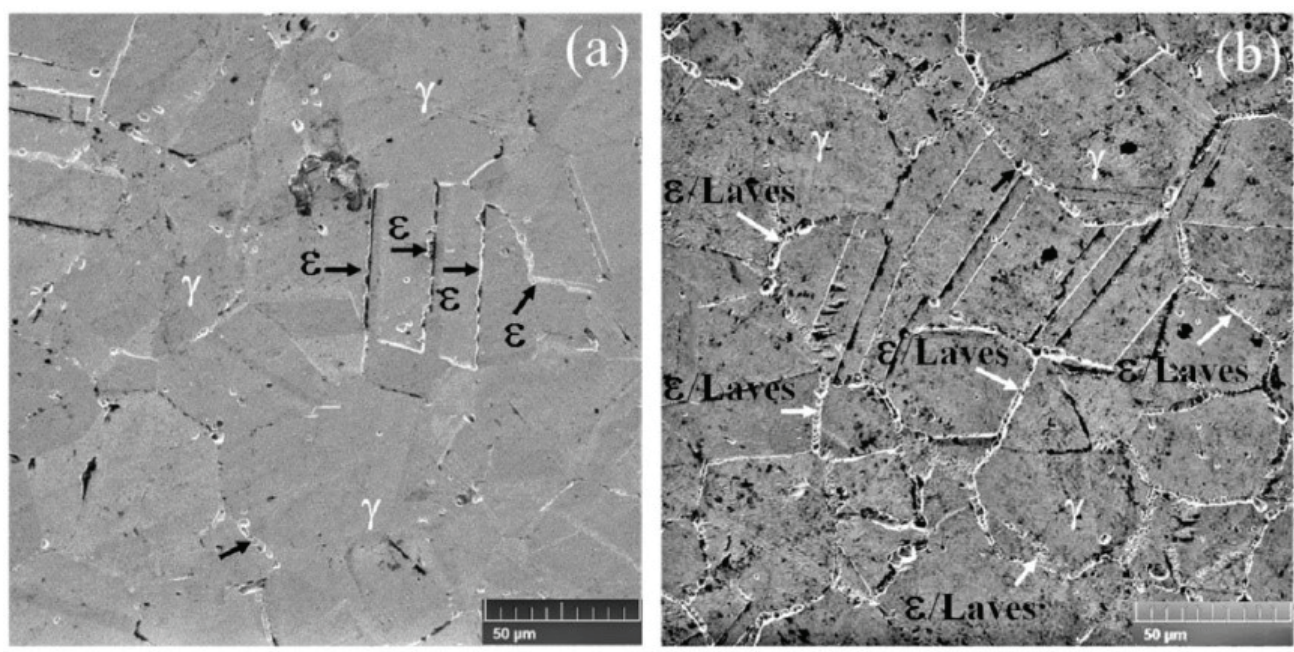

Figure 3. Microstructure of $0.4 \%$ Mo austenitic stainless steel: (a) aged at $650^{\circ} \mathrm{C}$; (b) aged at $900^{\circ} \mathrm{C}$. SEM $(1000 \mathrm{X}$ ).

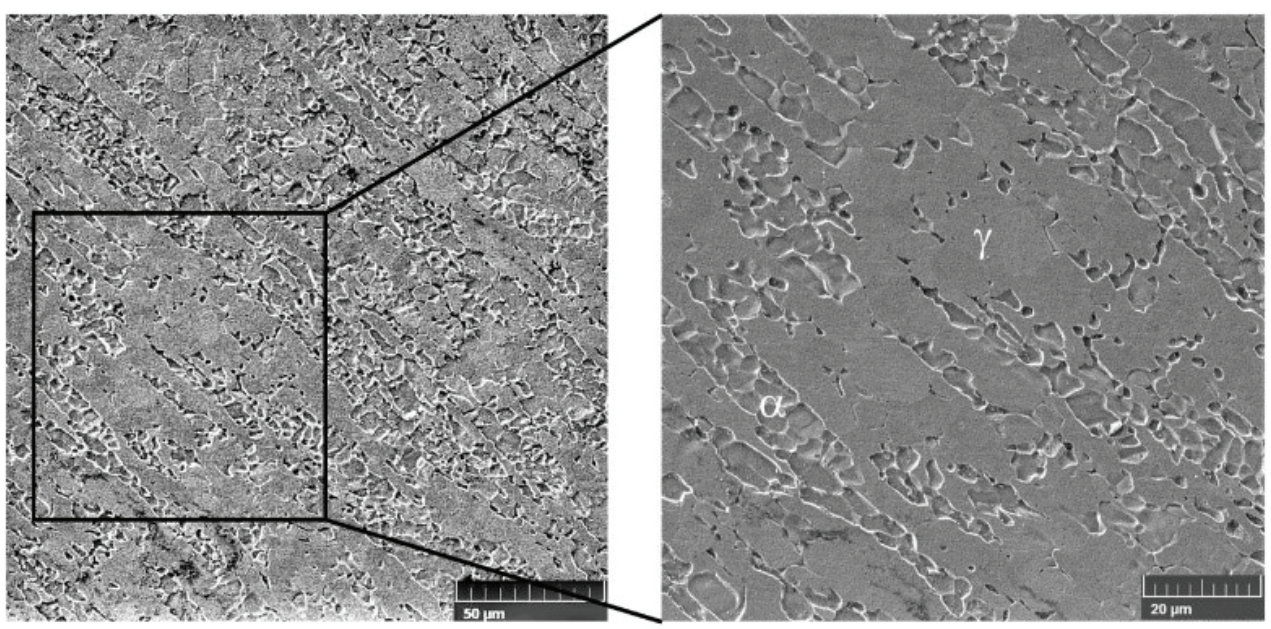

Figure 4. Microstructure of UNS S31803 duplex stainless steel aged at $650^{\circ} \mathrm{C}$ SEM.

$900^{\circ} \mathrm{C}$ compared to the sample aged at $650^{\circ} \mathrm{C}$. Intergranular corrosion is caused by precipitation of chromium-rich phases in the grain boundary ${ }^{1-4}$. In the sample aged at $900^{\circ} \mathrm{C}$, the electrolytic attack (oxalic acid aqueous solution at $10 \%$ by mass) showed the intergranular corrosion in the region of the grain boundary of the microstructure (chromium-poor region). In some regions, the precipitates were removed, leaving small "holes," as observed by Tavares et al. ${ }^{3}$. In Figure 3a, intergranular corrosion can also be observed in the sample aged at $650^{\circ} \mathrm{C}$, but with lower intensity compared to the sample aged at $900^{\circ} \mathrm{C}$. In both $0.4 \%$ Mo austenitic stainless steel samples, aged at $650^{\circ} \mathrm{C}$ (Figure $3 \mathrm{a}$ ) and aged at $900^{\circ} \mathrm{C}$ (Figure 3b), there were thermally activated twins in the steel microstructure. The micrographs of the $0.4 \%$ Mo austenitic stainless steel shown in Figure 3 confirm the results obtained in the DL-EPR tests. According to these tests, as shown in Figures 1 and 2, the sensitization degree of $0.4 \%$ Mo austenitic stainless steel aged at $900^{\circ} \mathrm{C}$ was higher than that aged at $650^{\circ} \mathrm{C}$.
Figures 4 and 5 show the micrographs of the UNS S31803 duplex stainless steel aged at $650^{\circ} \mathrm{C}$ and $900^{\circ} \mathrm{C}$ for $30 \mathrm{~min}$, followed by cooling in water at room temperature.

As shown in Figure 4, the steel microstructure aged at $650^{\circ} \mathrm{C}$ consisted of austenite $(\gamma)$ and ferrite $(\alpha)$ (identified by $\mathrm{SEM} / \mathrm{EBSD}$ analysis). In the sample aged at $650^{\circ} \mathrm{C}$, the electrolytic attack (oxalic acid aqueous solution at $10 \%$ by mass) did not show the intergranular corrosion in the region of the grain boundary of the microstructure. This behavior of the UNS S31803 steel aged at $650^{\circ} \mathrm{C}$ confirms the result obtained in the DL-EPR test where a low degree of sensitization was observed $(0.014 \pm 0.004)$. Although no intergranular corrosion was observed in the aged steel at $650^{\circ} \mathrm{C}$, considerable corrosion was induced by the electrolytic attack on the surface of the ferrite grains $(\alpha)$, as can be seen in Figure 4.

Figure 5 shows the microstructure of the UNS S31803 steel aged at $900^{\circ} \mathrm{C}$. The electrolytic attack (oxalic acid aqueous solution at $10 \%$ by mass) produced intense ferrite dissolution, 


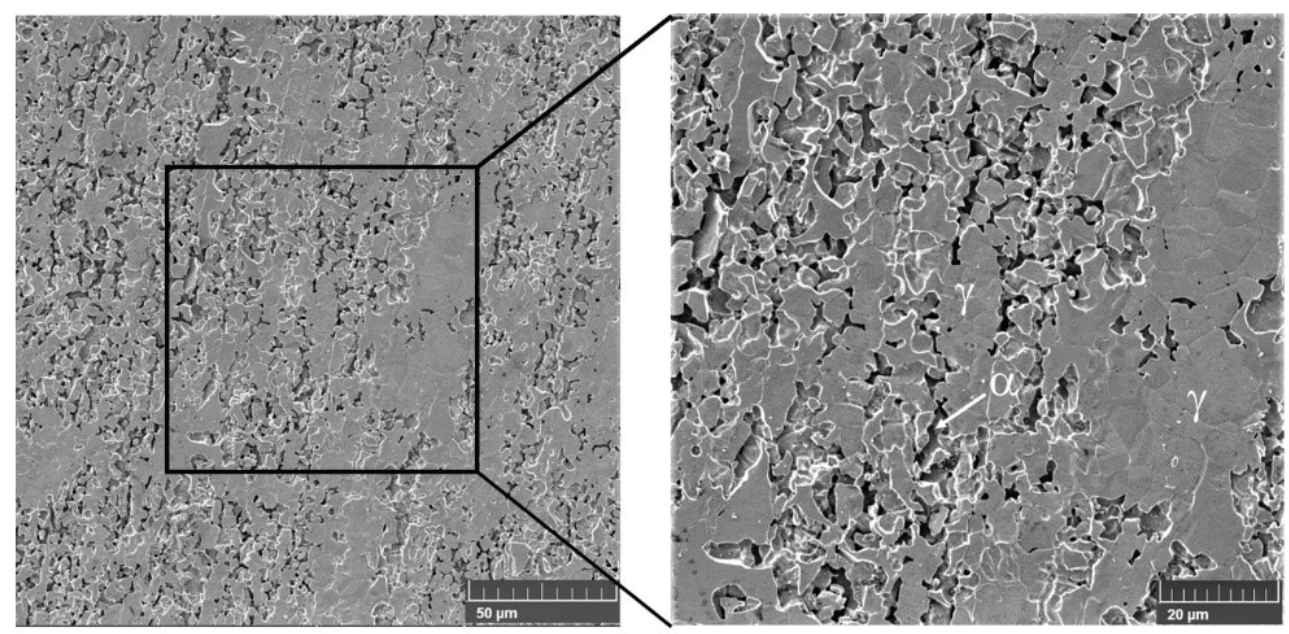

Figure 5. Microstructure of UNS S31803 duplex stainless steel aged at $900^{\circ} \mathrm{C}$. SEM.

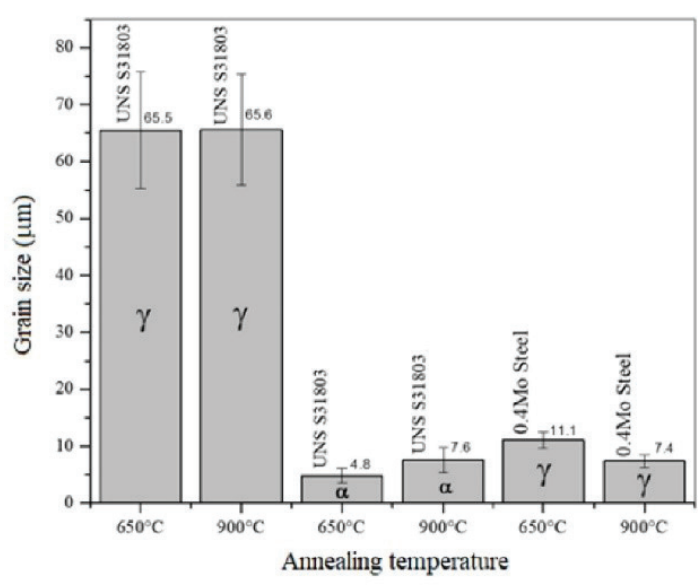

Figure 6. Grain sizes of $0.4 \%$ Mo austenitic and UNS S31803 duplex stainless steels.

giving rise to the phenomenon called "sugarin". Depending on the combination of intensity and sugarin intergranular corrosion, some grains of the material may be completely removed, affecting the mechanical strength of the steel ${ }^{11}$. As can be seen in Figure 5, the electrolytic attack produced intense dissolution of the ferrite grains. The small ferrite grain size in steel UNS S31803 (Figure 6) contributed to its elimination by electrolytic attack. The ferrite and austenite grain sizes of the steels, shown in Figure 6, were measured according to ASTM E-112-10 ${ }^{12}$.

Duplex stainless steels, when exposed to a certain temperature range $\left(650^{\circ} \mathrm{C}\right.$ to $\left.900^{\circ} \mathrm{C}\right)$, are susceptible to sigma phase precipitation. The sigma phase occurs inside the ferritic phase and on the grain boundary of ferrite-austenite grains. The precipitation of the sigma phase occurs due to the diffusion of $\mathrm{Cr}$ and Mo from the ferritic matrix. Thus, the ferrite is destabilized. The destabilization of the ferrite induces the formation of secondary austenite close to the formed sigma phase. Secondary austenite is poor in $\mathrm{Cr}$ and $\mathrm{Mo}$ and rich in Ni. As a consequence of this, the passive layer close to this region is very affected, favoring intergranular corrosion.

In the case of duplex stainless steels UNS S31803 aged at $900^{\circ} \mathrm{C}$, the large sigma phase precipitation (Figure $7 \mathrm{~d}$ ), associated with the small grain size of the ferrite, caused its severe selective corrosion.

Figure 7 shows the $0.4 \%$ Mo austenitic and UNS S31803 duplex stainless steel diffractograms. Both steels were aged at $650^{\circ} \mathrm{C}$ and $900^{\circ} \mathrm{C}$.

The presence of austenite $(\gamma)$ and the small intensity of epsilon phase $(\varepsilon)$ were indicated in the $0.4 \%$ Mo austenitic stainless steel aged at $650^{\circ} \mathrm{C}$ (Figure $\left.7 \mathrm{a}\right)^{13}$. The aging at $900^{\circ} \mathrm{C}$ (Figure $7 \mathrm{~b}$ ) caused greater $\varepsilon$ phase presence (higher diffraction peak at $2 \theta=64^{\circ}$ ) compared to steel aged at $650^{\circ} \mathrm{C}^{13,14}$. Also, in Figure $7 \mathrm{~b}$, the intermetallic phases called Laves were observed at $2 \theta=38^{\circ}$ in the $0.4 \%$ Mo austenitic stainless steel aged at $900^{\circ} \mathrm{C}^{15-17}$. The presence of Laves phases (with molybdenum) and the greater presence of $\varepsilon$ phase (rich in carbon) in $0.4 \%$ Mo austenitic stainless steel aged at $900^{\circ} \mathrm{C}$ can be considered the possible cause of the increase (approximately 30\%) in its degree of sensitization in relation to steel aged at $650^{\circ} \mathrm{C}$ (Table 2).

The UNS S31803 steel aged at $650^{\circ} \mathrm{C}$ (Figure 7c) showed ferrite and austenite phases with defined diffraction peaks. At this aging temperature no precipitate diffraction peaks were observed.

At $900^{\circ} \mathrm{C}$ aging temperature, in addition to ferrite $(\alpha)$ and austenite $(\gamma)$ phases, sigma $(\sigma)$ phase and epsilon phase $(\varepsilon)$ can be observed, as indicated in the diffractogram (Figure $7 d)^{18-20}$. The $\sigma$ phase is rich in chromium and molybdenum, and $\varepsilon$ phase is rich in carbon. In this case, the $\sigma$ phase can be considered the probable cause of the increased sensitization of the UNS S31803 steel aged at $900^{\circ} \mathrm{C}$ compared to the same one aged at $650^{\circ} \mathrm{C}$ (Table 2). The precipitation of the $\sigma$ phase caused the decrease of chromium and molybdenum in the regions near the grain boundary. The low content of chromium and molybdenum caused intense electrolytic attack on the grain boundary followed by dissolution of the ferrite grains (Figure 5). 

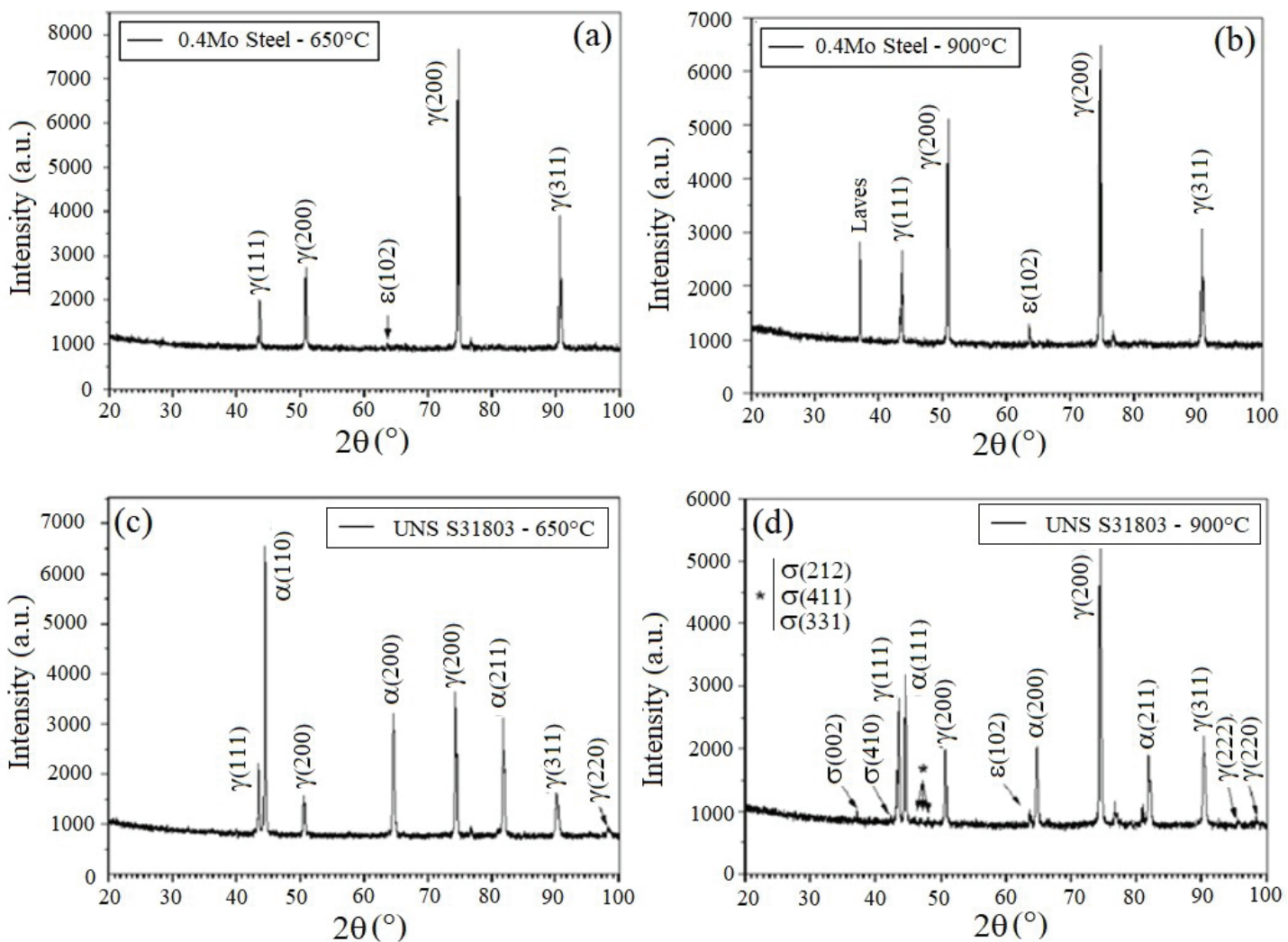

Figure 7. $0.4 \%$ Mo austenitic stainless steel and UNS S31803 duplex stainless steel diffractograms: (a) $0.4 \%$ Mo austenitic stainless steel aged at $650^{\circ} \mathrm{C}$; (b) $0.4 \%$ Mo austenitic stainless steel aged at $900^{\circ} \mathrm{C}$; (c) UNS S31803 duplex stainless steel aged at $650^{\circ} \mathrm{C}$; (d) UNS S31803 duplex stainless steel aged at $900^{\circ} \mathrm{C}$.

\section{Conclusions}

- The DL-EPR test allowed correlation of the influence of thermal aging on the degree of sensitization of the $0.4 \%$ Mo austenitic and UNS S31803 duplex stainless steels.

- $\quad$ The $0.4 \%$ Mo austenitic and UNS S31803 duplex stainless steels when subjected at $900^{\circ} \mathrm{C}$ aging treatment for 30 minutes presented a higher degree of sensitization when compared to the treatment at $650^{\circ} \mathrm{C}$ at the same time.

- $\quad$ The $0.4 \%$ Mo austenitic stainless steel presented higher degrees of sensitization than the UNS S31803 duplex stainless steel at both temperatures studied: $650^{\circ} \mathrm{C}$ and $900^{\circ} \mathrm{C}$. This can be attributed to a lower resistance of the passive layer of $0.4 \%$ Mo austenitic stainless steel in the grain boundary region, due to its lower chromium and higher carbon content (formation of rich in chromium precipitated). The presence of ferrite in the microstructure of the UNS S31803 steel, may also have contributed to minimize the sensitization of this steel compared to $0.4 \%$ Mo Austenitic stainless steel.

\section{Acknowledgements}

The authors would like to acknowledge the GPESE (Grupo de Pesquisa em Sistemas de Exaustão), UNIFEI
(Universidade Federal de Itajubá, Campus Itabira - Brazil), for providing the equipment and technical support for experiments and Professor Guilherme Oliveira Siqueira for XRD analysis support.

\section{References}

1. Ortiz N, Curiel FF, López VH, Ruiz A. Evaluation of the intergranular corrosion susceptibility of UNS S31803 duplex stainless steel with thermoelectric power measurements. Corros Sci. 2013;69:236-44.

2. Kosec L, Šavli Š, Kožuh S, Grgurić TH, Nagode A, Kosec $\mathrm{G}$, et al. Transformation of austenite during isothermal annealing at $600-900{ }^{\circ} \mathrm{C}$ for heat-resistant stainless steel. J Alloys Compd. 2013;567:59-64.

3. Tavares SSM, Silva FJ, Scandian C, Silva GF, Abreu H F G. Microstructure and intergranular corrosion resistance of UNS S17400 (17-4PH) stainless steel. Corros Sci. 2010;52(11):38359.

4. Zhang S, Jiang Z, Li H, Feng H, Zhang B. Detection of susceptibility to intergranular corrosion of aged super austenitic stainless steel S32654 by a modified electrochemical potentiokinetic reactivation method. J Alloys Compd. 2017;695:3083-93.

5. Hong J, Han D, Tan H, Li J, Jiang Y. Evaluation of aged duplex stainless steel UNS S32750 susceptibility to intergranular corrosion by optimized double loop electrochemical potentiokinetic reactivation method. Corros Sci. 2013;68:249-55.

6. Kang DH, Lee HW. Study of the correlation between pitting corrosion and the component ratio of the dual phase in duplex stainless steel welds. Corros Sci. 2013;74:396-407. 
7. Č́hal V, Štefec R. On the development of the electrochemical potentiokinetic method. Electrochim Acta. 2001;46(24-25):3867-77.

8. Assis KS, Rocha AC, Margarit-Mattos IC, Serra F A S, Mattos OR. Practical aspects on the use of on-site Double Loop Electrochemical Potentiodynamic Reactivation Technique (DLEPR) for Duplex Stainless Steel. Corros Sci. 2013;74:250-5.

9. Jeon SH, Kim ST, Lee IS, Kim JS, Kim KT, Park YS. Effects of W substitution on the precipitation of secondary phases and the associated pitting corrosion in hyper duplex stainless steels. J Alloys Compd. 2012;544:166-72.

10. Khan Z, Fida S, Nisar F, Alam N. Investigation of Intergranular Corrosion in 2nd stage gas turbine blades of an aircraft engine. Eng Fail Anal. 2016;68:197-209.

11. Baboian R. Corrosion tests and standards: application and Interpretation. 2nd ed. West Conshohoken: ASTM International; 1995.

12. American Society for Testing \& Materials - ASTM. ASTM E-112-10: standard test methods for determining average grain size. West Conshohocken: ASTM; 2010.

13. Soares GC, Gonzalez BM, Santos LA. Strain hardening behavior and microstructural evolution during plastic deformation of dual phase, non-grain oriented electrical and AISI 304 steels. Mater Sci Eng A. 2017;684:577-85

14. Li X, Lo KH, Kwok CT, Sun YF, Lai KK. Post-fire mechanical and corrosion properties of duplex stainless steel: comparison with ordinary reinforcing-bar steel. Constr Build Mater. 2018; $174: 150-8$.
15. Tan L, Yang Y. In situ phase transformation of laves phase from Chi-phase in Mo-containing $\mathrm{Fe}-\mathrm{Cr}-\mathrm{Ni}$ alloys. Mater Lett. 2015;158:233-6.

16. Abra-Arzola JL, García-Rentería MA, Cruz-Hernández VL, García-Guerra J, Martínez-Landeros VH, Falcón-Franco LA, et al. Study of the effect of sigma phase precipitation on the sliding wear and corrosion behaviour of duplex stainless steel AISI 2205. Wear. 2017;400:43-51.

17. Wang W, Song R, Peng S, Pei Z. Multiphase steel with improved impact-abrasive wear resistance in comparison with conventional Hadfield steel. Mater Des. 2016;105:96-105.

18. Maj P, Adamczyk-Cieslak B, Nowicki J, Mizera J, Kulczyk M. Precipitation and mechanical properties of UNS 2205 duplex steel subjected to hydrostatic extrusion after heat treatment. Mater Sci Eng A. 2018;734:85-92.

19. Yang SM, Chen YC, Chen CH, Huang WP, Lin DY. Microstructural characterization of $\delta / \gamma / \sigma / \gamma 2 / \chi$ phases in silver-doped 2205 duplex stainless steel under $800^{\circ} \mathrm{C}$ aging. J Alloys Compd. 2015;633:48-53.

20. Li J, Du CW, Liu ZY, Li XG, Liu M. Effect of microstructure on the corrosion resistance of 2205 duplex stainless steel. Part 1: microstructure evolution during isothermal aging at $850^{\circ} \mathrm{C}$ and evaluation of anticorrosion properties by methods of cyclic potentiodynamic polarization and electrochemical impedance tests. Constr Build Mater. 2018;189:1286-93. 